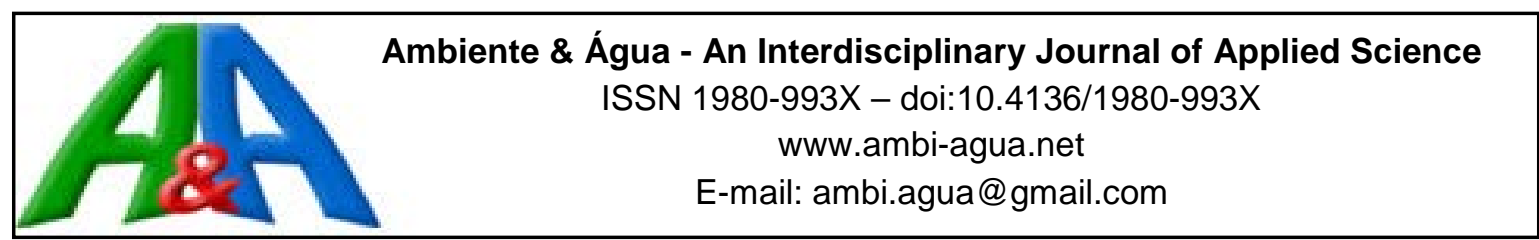

\title{
Cost of charging for water use in the Brazilian Cerrado hydrographic basin
}

ARTICLES doi:10.4136/ambi-agua.2238

Received: 07 Feb. 2018; Accepted: 27 Aug. 2018

\author{
Kalesson Martins Alencar ${ }^{1 *}$; Michel Castro Moreira ${ }^{2}$; Demetrius David da Silva ${ }^{3}$ \\ ${ }^{1}$ Universidade Federal do Oeste da Bahia (UFOB), Barreiras, BA, Brasil \\ Coordenadoria de Gestão Administrativa (CGA). E-mail: kalesson.alencar@gmail.com \\ ${ }^{2}$ Universidade Federal do Oeste da Bahia (UFOB), Barreiras, BA, Brasil \\ Centro das Ciências Exatas e das Tecnologias (CCET). E-mail: michelcm@ufob.edu.br \\ ${ }^{3}$ Universidade Federal de Viçosa (UFV), Viçosa, MG, Brasil \\ Departamento de Engenharia Agrícola (DEA). E-mail: demetrius@ufv.br \\ ${ }^{*}$ Corresponding author
}

\begin{abstract}
This study analyzed the relative cost of charging for water use with respect to water users' production costs in the Grande River Basin, located in the Brazilian Cerrado, considering the principal charging methods existing in Brazil. The study was developed based on: the rights of use grant data surveys pertaining to water resources and the classification of bodies of water into usage classes; a simulation of charging for water use through various methods; and an analysis of the relative cost of charges on the production cost of the water users. The charging methods used by the following were studied: the Committee of the Basin of River Paraíba do Sul (CEIVAP), the Committee of Basins of Piracicaba, Capivari and Jundiaí Rivers (PCJ), the São Francisco River Basin Committee (CBHSF) and the Doce River Basin Committee (CBHDOCE). The study verified that irrigated agriculture is the sector that uses the most water, representing $46.4 \%$ of the outflow granted in the basin. Considering the different charging methods, the collection in the basin of the Grande River potentially allows for investments of US\$ 1.2 million (PCJ), US\$ 920,000 (CEIVAP), US\$ 426,000 (CBH-DOCE), or US\$ 297,000 (CBHSF) in this region, leading to average relative costs of $0.68 \%$ (irrigation), $0.28 \%$ (human) and $0.08 \%$ (industry). For this reason, there is the possibility of implanting charges for water use in the Grande River Basin, with either the CEIVAP's or PCJ's method appearing to be the most suitable, given that the parameters of these mechanisms are in line with existing activities in the basin.
\end{abstract}

Keywords: Brazilian Cerrado, water price, water resources management.

\section{Custo da cobrança pelo uso da água em bacia hidrográfica do Cerrado Brasileiro}

\section{RESUMO}

Este trabalho teve por objetivo analisar o custo relativo da cobrança pelo uso da água em relação aos custos de produção dos usuários na bacia do rio Grande, localizada no Cerrado Brasileiro, considerando os principais mecanismos de cobrança existentes no Brasil. O trabalho foi desenvolvido a partir do levantamento dos dados de outorga dos direitos de uso de recursos 
hídricos e de enquadramento dos corpos de água em classes de uso; da simulação da cobrança pelo uso da água utilizando diferentes mecanismos de cobrança; e da análise do custo relativo da cobrança no custo de produção dos usuários de água. Foram estudados os mecanismos de cobrança do Comitê para Integração da Bacia Hidrográfica do rio Paraíba do Sul (CEIVAP), Comitê da Bacia Hidrográfica dos rios Piracicaba, Capivari e Jundiaí (PCJ), Comitê da Bacia Hidrográfica do rio São Francisco (CBHSF) e Comitê da Bacia Hidrográfica do rio Doce (CBHDOCE). O levantamento dos dados de outorga permitiu verificar que a agricultura irrigada é o setor que mais utiliza água, representando $46.4 \%$ da vazão outorgada na bacia. A cobrança na bacia do rio Grande, considerando os diferentes mecanismos de cobrança, poderia permitir investimentos nessa região na ordem de US\$ 1.2 milhão (PCJ), US\$ 920 mil (CEIVAP), US\$ 426 mil (CBH-DOCE), ou de US\$ 297 mil (CBHSF), gerando impactos econômicos médios de $0.68 \%$ (irrigação), $0.28 \%$ (humano) e $0.08 \%$ (indústria). Deste modo, há possibilidade de implantação da cobrança pelo uso da água na bacia do rio Grande, sendo o mecanismo do CEIVAP ou o do PCJ os mais adequados, haja vista os parâmetros destes mecanismos estarem alinhados às atividades existentes na bacia.

Palavras-chave: Cerrado Brasileiro, gestão de recursos hídricos, preço da água.

\section{INTRODUCTION}

Demands from different users have been causing conflicts over water use worldwide (Garcia-Valiñas et al., 2013; Nazer et al., 2010). The main reason for these disputes lies in water's qualitative and quantitative limitations (Wolf et al., 2005), which has spurred many countries to review and or introduce legislation related to the management of water resources (Veiga and Magrine, 2013).

Among the management instruments provided for in the National Water Resources Policy (NWRP), established by Law No.9.433/1997 in Brazil, charging for using water resources seeks to: "recognize water as an economic property and make users aware of its real value; to stimulate the rationalization of water use; and to get financial resources for subsidizing the programs and interventions covered in the plans for water resources” (Brazil, 1997).

The attainment of financial resources by means of charging enables interventions in the basin that can provide improvements in the quality and amount of water, as well as reducing environmental degradation. Ploeg and Sommerfeld (2011) explain that charging is an effective tool to encourage the conservation and protection of water resources, whereas Johnson et al. (2002) point out that investment in the sustainable management of the basin can be significantly lower than the expenses necessary to obtain new forms of water supply or treatment.

Charging is already enforced in various river basins across Brazil, such as the Paraíba do Sul River; Piracicaba, Capivari and Jundiaí Rivers; São Francisco and Doce Rivers, which use the main existing charging methods in Brazil. They were established, respectively, by the Committee for the Integration of the Hydrographic Basin of River Paraíba do Sul (CEIVAP), Committee of Hydrographic Basins of Piracicaba, Capivari and Jundiaí Rivers (PCJ), São Francisco River Hydrographic Basin Committee (CBHSF) and Doce River Hydrographic Basin Committee (CBH-DOCE).

In 2015, Brazil collected approximately US\$ 92.3 million with the from charges for water use from river basins (ANA, 2016). This situation demonstrates the involvement of water basin users, as defaults did not exceed 10\% of the amount charged in 2014.

Charging for using water resources is highly important in places where there is a high demand on water use, such as occurs in the Grande River Basin, located in the western part of the state of Bahia, in a region characterized by Cerrado Biome. This biome is considered a biodiversity hotspot (Araújo et al., 2012), and with an area of approximately 2 million 
kilometers (Klink and Machado, 2005), it is the second largest in Brazil (Souza et al., 2016). The expansion of agribusiness in the region has accelerated the destruction of this biome, because more than half of its area has been transformed into pastures and grain crops, among other uses (Klink and Machado, 2005), and it has also been threatened by the expansion of sugar cane (Carvalho et al., 2009).

According to AIBA (2015), Western Bahia is renowned for its agribusiness strength, having produced 7.4 million tons of agricultural products in 2014-2015 in a 2.3-million-hectare area, especially soybeans, maize and cotton. The region has a predominance of withdrawal for irrigation flows compared to other uses, representing more than $60 \%$ of the total demand (ANA, 2013).

Given the importance of the Grande River Basin, most notably through conservation needs for the Cerrado Biome, its intensely irrigated agriculture and the hydroelectric potential of the region, this study sought to analyze the relative cost of charging for water use with respect to water users' production costs in the Grande River Basin, taking the main charging methods existing in Brazil into account, aiming to provide a basis for the implementation of this management tool in order to contribute to the multiple and rational use of water.

\section{MATERIALS AND METHODS}

\subsection{Study area}

In order to analyze the relative cost of charging for water use and taking the main charging methods existing in Brazil into account, this work was carried out in the Grande River Basin, Western State of Bahia, in a region of the Cerrado Biome (Figure 1).

The Grande River Basin has an area of $78,500 \mathrm{~km}^{2}$ and corresponds to $13.9 \%$ of the State of Bahia (Almeida et al. 2014). The Grande River produces the third largest water source flowing into the São Francisco River Basin (Feitosa and Santos, 2016; Pereira et al., 2007); however, there have been conflicts over water use. Thus, proper management of its water resources is required (Moreira and Silva, 2010).

The basin comprises 17 municipalities in Western Bahia where the climate ranges from humid to semi-arid (INEMA, 2014), and the Cerrado is its predominant biome (Santos and Castro 2016). As per Passo et al. (2010), the introduction of agriculture in the Cerrado of Bahia, notably in Western Bahia, has effected a change in the economic, political and geographic profile of the region - a milestone in the Brazilian economic scene.

\subsection{Grants and guidelines}

Considering that the Brazilian legislation only allows charging for water use subject to the granting instrument, the Institute for the Environment and Water Resources (INEMA) has provided the Grande River Basin grants data, issued up to September 2015, as INEMA is the managing agency of water resources for the State of Bahia.

The waters from rivers are classified under CONAMA's resolution No. 357/2005, according to the quality required for their preponderant uses (special, I, II, III or IV classes) (CONAMA, 2005). This classification is required in order to meet the most demanding uses in each section of the basin, and it is fundamental to understand the uses and quality needed before implementing charges

The framework class of the rivers from the Grande River Basin was provided by the São Francisco River Hydrographic Basin Committee (CBHSF), in its Water Resources Plan (ANA et al., 2004), since the Grande River Basin is a sub-basin of the São Francisco River Basin (Figure 1).

\section{IPABH}



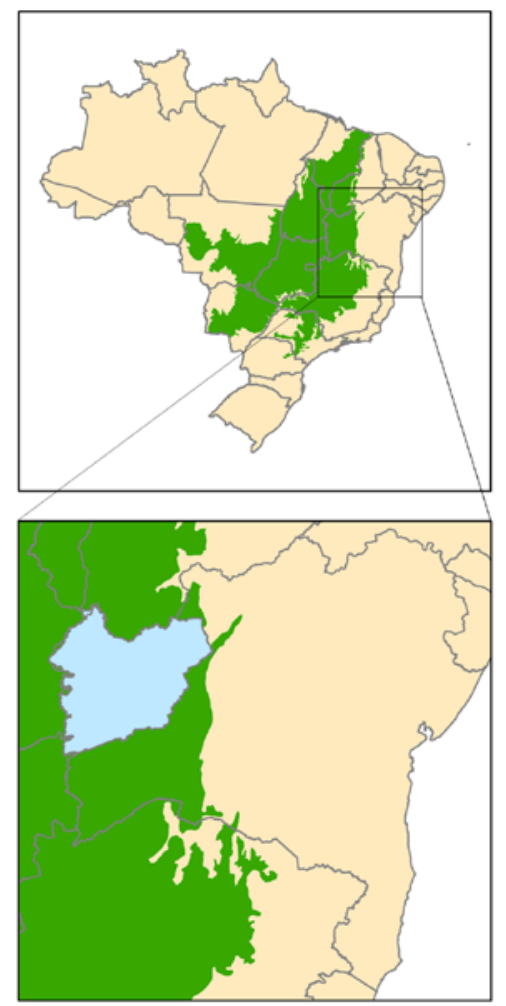

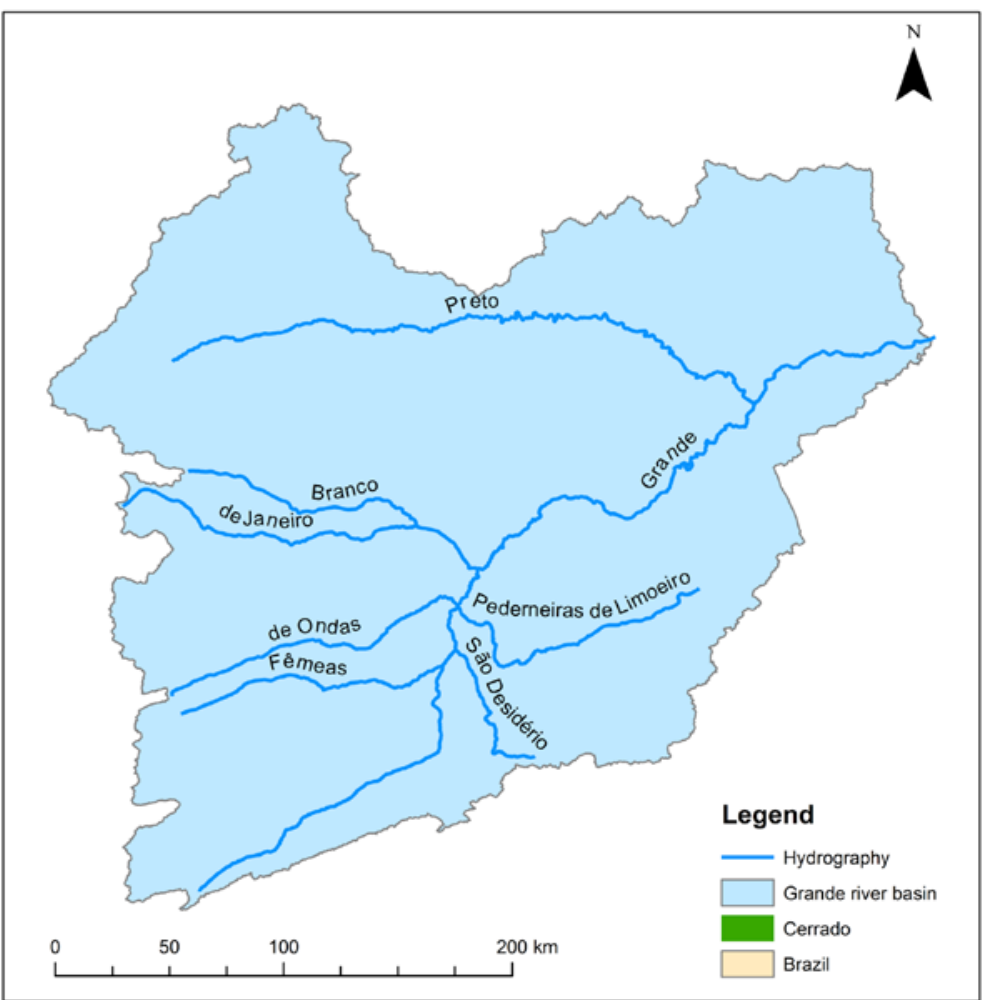

Figure 1. Location of the Grande River Basin.

\subsection{Simulation of water use charges through different methods}

The simulation of water-use charges in the Grande River Basin was carried out through methods adopted by the Committee for the Integration of the Hydrographic Basin of theParaíba do Sul River (CEIVAP); the Committee of the Hydrographic Basins of the Piracicaba, Capivari and Jundiaí Rivers (PCJ); the São Francisco River Hydrographic Basin Committee (CBHSF) and the Doce River Hydrographic Basin Committee (CBH-DOCE). The parameters and Equations 1, 2, 3 and 4 used in the simulation of the charges were obtained by CEIVAP (2014); PCJ (2007; 2012); CBHSF (2008; 2010) and CBH-DOCE (2011).

$\mathrm{VT}_{\text {CEIVAP }}=\left(\mathrm{V}_{\mathrm{CAP}}+\mathrm{V}_{\mathrm{CONS}}+\mathrm{V}_{\mathrm{DBO}}\right) \cdot \mathrm{K}_{\text {management }}$

where the

$\mathrm{VT}_{\text {CEIVAP }}=$ total value of the annual payment for water use, in US\$ year ${ }^{-1}$;

$\mathrm{V}_{\text {CAP }}=$ value of the annual payment for water catchment, in US\$ year ${ }^{-1}$;

$\mathrm{V}_{\text {cons }}=$ value of the annual payment for water consumption, in US\$ year ${ }^{-1}$;

$\mathrm{V}_{\text {DBO }}=$ value of the annual payment for organic load release, in US\$ year ${ }^{-1}$; and

$\mathrm{K}_{\text {management }}=$ coefficient of management, dimensionless.

$\mathrm{VT}_{\mathrm{PCJ}}=\left(\mathrm{V}_{\mathrm{CAP}}+\mathrm{V}_{\mathrm{CONS}}+\mathrm{V}_{\mathrm{DBO}}+\mathrm{V}_{\mathrm{SHP}}+\mathrm{V}_{\text {rural }}+\mathrm{V}_{\text {transp }}\right) \cdot \mathrm{K}_{\text {management }}$

where the

$\mathrm{VT}_{\mathrm{PCJ}}=$ total value of the annual payment for water use, in US\$ year ${ }^{-1}$;

$\mathrm{V}_{\mathrm{CAP}}=$ value of the annual payment for water catchment, in US\$ year $^{-1}$; 
$\mathrm{V}_{\text {cons }}=$ value of the annual payment for water consumption, in US\$ year ${ }^{-1}$;

$\mathrm{V}_{\mathrm{DBO}}=$ value of the annual payment for organic load release, in US\$ year ${ }^{-1}$;

$\mathrm{V}_{\mathrm{SHP}}=$ value of the annual payment for water use for hydroelectric generation in a Small Hydroelectric Plant (SHP), in US\$ year ${ }^{-1}$;

$\mathrm{V}_{\text {rural }}=$ value of the annual payment for water catchment and consumption for users of the rural sector, in US\$ year ${ }^{-1}$;

$\mathrm{V}_{\text {transp }}=$ value of the annual payment for water transposition, in US\$ year ${ }^{-1}$; and

$\mathrm{K}_{\text {management }}=$ coefficient of management, dimensionless.

$\mathrm{VT}_{\mathrm{CBHSF}}=\left(\mathrm{V}_{\mathrm{CAP}}+\mathrm{V}_{\mathrm{CONS}}+\mathrm{V}_{\mathrm{DBO}}\right) \cdot \mathrm{K}_{\mathrm{management}}$

where the

$\mathrm{VT}_{\mathrm{CBHSF}}=$ total value of the annual payment for water use, in US\$ year $^{-1}$;

$\mathrm{V}_{\mathrm{CAP}}=$ value of the annual payment for water catchment, in US\$ year ${ }^{-1}$;

$\mathrm{V}_{\text {cons }}=$ value of the annual payment for water consumption, in US\$ year ${ }^{-1}$;

$\mathrm{V}_{\mathrm{DBO}}=$ value of the annual payment for organic load release, in US\$ year ${ }^{-1}$; and

$\mathrm{K}_{\text {management }}=$ coefficient of management, dimensionless .

$\mathrm{VT}_{\mathrm{CBH}-\mathrm{Doce}}=\left(\mathrm{V}_{\mathrm{CAP}}+\mathrm{V}_{\text {disp }}+\mathrm{V}_{\text {transp }}+\mathrm{V}_{\mathrm{SHP}}\right) \cdot \mathrm{K}_{\text {management }}$

where the

$\mathrm{VT}_{\mathrm{CBH}-\mathrm{Doce}}=$ total value of the annual payment for water use, in US\$ year ${ }^{-1}$;

$\mathrm{V}_{\mathrm{CAP}}=$ value of the annual payment for water catchment, in US\$ year ${ }^{-1}$;

$\mathrm{V}_{\text {laun }}=$ value of the annual payment for organic load release, in US\$ year $^{-1}$;

$\mathrm{V}_{\text {transp }}=$ value of the annual payment for water transposition, in US\$ year ${ }^{-1}$;

$\mathrm{V}_{\mathrm{SHP}}=$ value of the annual payment for water use for hydroelectric generation in a Small Hydroelectric Plant (SHP), in US\$ year ${ }^{-1}$; and

$\mathrm{K}_{\text {management }}=$ coefficient of management, dimensionless.

\subsection{Analysis of the relative cost of charging on the production costs of water users}

In order to analyze the relative cost of charging for water on the production costs of water users, considering simulated charging methods, it was necessary to determine the total cost of production, in US\$ per year ${ }^{-1}$, for each one of the Grande River Basin’s user segments.

For irrigation, an average of the production costs for the three major crops in the region (maize, cotton and soy) was carried out, in US\$ per ha" ${ }^{-1}$ per year ${ }^{-1}$, with the costs based on data provided by CONAB (2015).

\section{IPABH}

Rev. Ambient. Água vol. 13 n. 5, e2238 - Taubaté 2018 
For animal consumption, costs were obtained from the Development Agency of the State of Bahia (DESENBAHIA, 2010), which were updated up to 2015 through livestock indicators from the Centre for Advanced Studies in Applied Economics (CEPEA) (CEPEA, 2016).

In relation to human supply and sanitation, costs were calculated based on the tariffs for commercial derivations of raw water of the Bahia Water and Sanitation Company (EMBASA). The determination of the total annual cost considered the flow granted and the annual consumption of the segment.

For the industrial supply, the following were taken into account: costs of production (US\$ per year $^{-1}$ ) obtained in the state of Santa Catarina (2012); the produced amount ( $\mathrm{t}$ per year ${ }^{-1}$ ), found in Bunge (2012); and the water demand for the food industry, obtained from CNI (2013).

In relation to sand mining in the river stream bed, production costs (US\$ per $\mathrm{t}^{-1}$ ) were obtained in DNPM (2015); the water demand for the extraction of sand came from MMA (Brasil, 2011). The relative cost was analyzed using the value of the charges through different methods and the costs of production for each segment, using Equation 5:

$\mathrm{RC}=\frac{\mathrm{TV}}{\mathrm{PC}}$

where the

$$
\begin{aligned}
& \mathrm{RC}=\text { relative cost of payment for water use, in \%; } \\
& \mathrm{TV}=\text { total value of charges for water use, in US\$ year }{ }^{-1} \text {; and } \\
& \mathrm{PC}=\text { production cost of the segment in analysis, US\$ year }{ }^{-1} \text {. }
\end{aligned}
$$

\section{RESULTS AND DISCUSSION}

\subsection{Grande River Basin Grants}

In the database of grants supplied by INEMA, there were 171 current grants in the Grande River Basin in September of 2015. Among those, 80 are intended for irrigation; 24 for animal watering; 20 for human supply; 16 for sanitation; 28 for industrial supply; two for sand mining; and one for a small hydroelectric plant (SHP). The total outflow granted in the Grande River Basin was $1,479,774,188.9 \mathrm{~m}^{3}$ per year-1 or $46.9 \mathrm{~m}^{3} \mathrm{~s}^{-1}$, as shown in Table 1 .

As per the analysis of figures presented in Table 1, irrigation has found to have a greater representativeness in terms of grants, comprising $46.4 \%$ of the flow rate granted in the Grande River Basin. The data confirm that the region is predominantly agricultural and the water is heavily used by this segment.

In addition, there were 332 processes considered insignificant uses in the database supplied by INEMA. The insignificant uses are exempted from the grant, but they total an outflow of $2,373,580.4 \mathrm{~m}^{3}$ per year-1 or $0,075 \mathrm{~m}^{3} \mathrm{~s}^{-1}$ in the Grande River Basin. The flow rate corresponding to the insignificant uses represents $0.2 \%$ of the flow grant in the basin, which is an insignificant value when compared to irrigated agriculture, but higher than the flow intended for animal watering, human supply and sand mining, as shown in Figure 2.

There is no consensus as to what is insignificant or little use. There is a tendency to abolish the insignificant term, since water uses do not fit into this category (ANA et al., 2004). The CEIVAP and CBH-Doce, in the Minas Gerais section of the basin, assume the derivations and catchments of up to $1 \mathrm{l} \mathrm{s}^{-1}$ or $86.4 \mathrm{~m}^{3}$ per day ${ }^{-1}$ as being of little significance (CEIVAP, 2014; $\mathrm{CBH}-D o c e, 2011)$. CBH-Doce, in the Espírito Santo stretch of the basin, considers $1.5 \mathrm{l} \mathrm{s}^{-1}$ or 
$129.6 \mathrm{~m}^{3}$ per day ${ }^{-1}$ as insignificant use (CBH-Doce, 2011), while CBHSF considers $4 \mathrm{l} \mathrm{s}^{-1}$ or 345, $6 \mathrm{~m}^{3}$ per day ${ }^{-1}$ in the main river channel and the PCJ adopts $5 \mathrm{~m}^{3}$ per day ${ }^{-1}$ as a low expression use (PCJ, 2007).

Correct identification of significant or insignificant uses becomes fundamental in the process of charging for water use because the uses that are considered insignificant are not charged. In accordance with ANA et al. (2004), the exemption of payment for water use derives from the stipulation of insignificant use as per Law No. 9,433 of 1997, stating that it must previously be proposed by the committee of the hydrographic basin for approval by the Board of Water Resources, after negotiations with users, the public authorities and the representatives of civil society.

Table 1. Water Use in the Grande River Basin.

\begin{tabular}{lcccc}
\hline Type of use & $\begin{array}{c}\text { Number of } \\
\text { grants }\end{array}$ & $\mathbf{\%}$ & $\begin{array}{c}\text { Outflow granted } \\
\left(\mathbf{m}^{\mathbf{3}} \text { year }^{-\mathbf{~}} \mathbf{)}\right.\end{array}$ & $\mathbf{\%}$ \\
\hline Irrigation & 80 & 46.8 & $687,233,628.9$ & 46.4 \\
Animal watering & 24 & 14.0 & $1,860,040.0$ & 0.1 \\
Human supply & 20 & 11.7 & $1,904,205.0$ & 0.1 \\
Sanitation & 16 & 9.4 & $404,720,395.0$ & 27.4 \\
Industrial supply & 28 & 16.4 & $5,569,170.0$ & 0.4 \\
Sand mining & 2 & 1.2 & $54,750.00$ & 0.01 \\
Small Hydroelectric Plant (SHP) & 1 & 0.6 & $378,432,000.00$ & 25.6 \\
\hline Total & $\mathbf{1 7 1}$ & $\mathbf{1 0 0}$ & $\mathbf{1 , 4 7 9 , 7 7 4 , 1 8 8 . 9 0}$ & $\mathbf{1 0 0}$ \\
\hline
\end{tabular}

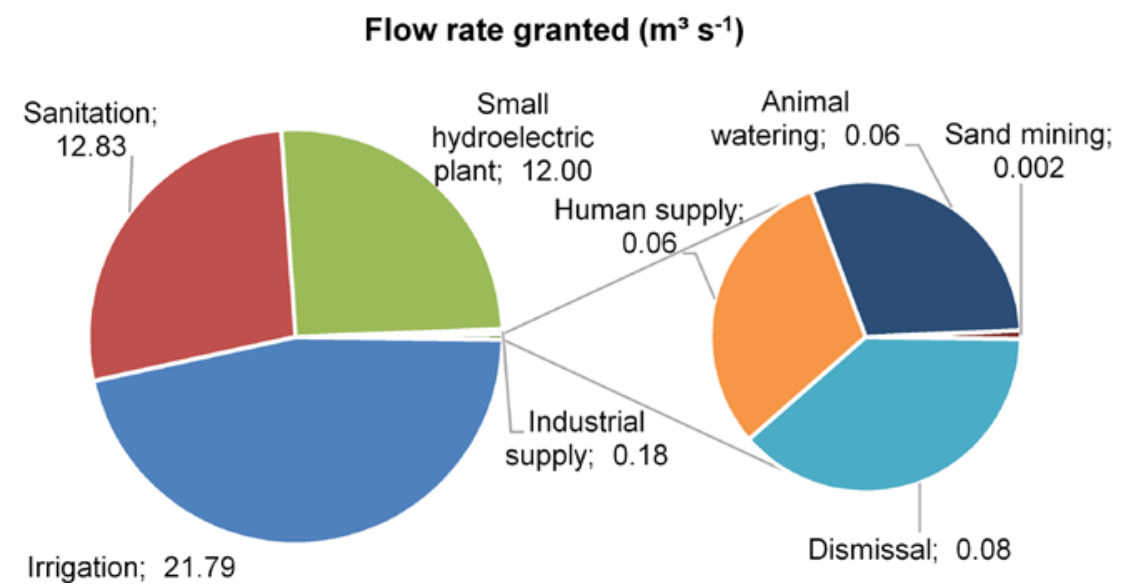

Figure 2. Dismissals of grant and other uses of water, in $\mathrm{m}^{3} \mathrm{~s}^{-1}$, in the Grande River Basin.

\subsection{Simulation for charging of water use using different methods}

The intensive use of irrigated agriculture characteristic of the region was demonstrated in the simulation of the CEIVAP's methods, representing $82.7 \%$ of the collection, followed by sanitation, at $8.7 \%$, and industrial supply, at $6.2 \%$. Other sectors were insignificant when considering the amount collected, since the representativeness did not exceed $2.1 \%$ of the simulated value, as shown in Table 2.

CEIVAP's method adopted progressive charging in its implementation in the Paraíba do Sul River Basin, but only for the agricultural and aquaculture sectors. According to this definition, the users included must pay $80 \%$ of the value charged in 2015 . By 2016, users should pay $90 \%$ of the amount charged, and in 2017 they must pay the total amount charged.

The estimated value of charging by PCJ's method exhibited a value close to the one simulated by CEIVAP's method, except for irrigation and sand mining. The difference for the 
irrigated agriculture was generated by the progressivity adopted by CEIVAP. For sand mining in the river stream bed, the discrepancy occurred because CEIVAP's method has specific parameters for this usage activity. The similarity between the simulations is linked to the similarity between the charging methods, which have public unitary prices (PUP) as a basic difference. The PUPs are values charged in US\$ $\mathrm{m}^{-3}$ for superficial catchment, consumption or waste discharges into water bodies.

The progressivity adopted by CEIVAP for the user segment of agriculture and aquaculture is an important strategy in encouraging an acceptance of the charges. The methodology followed allows the user to adapt to the charging process, paying a lower value initially, which is raised gradually until the full charge is reached.

The simulated charge values from CBHSF's methods and CBH-DOCE have proven to be different from CEIVAP's and PCJ's methods, but similar to each other. For the CBHSF's and CBH-DOCE's methods, the factor that justified the difference between these was the coefficient for irrigation, animal husbandry and aquaculture $(\mathrm{Kt})$, whose value of 0.025 substantially lowers the collection when these methods are applied. However, the simulated value was close to the other methods for human supply, sanitation (except CBH-DOCE), industrial supply and sand mining (except CEIVAP).

Table 2. Simulation of the charges for water use in the Grande River Basin considering different methods.

\begin{tabular}{|c|c|c|c|c|c|c|c|c|}
\hline $\begin{array}{l}\text { Type of } \\
\text { use }\end{array}$ & $\begin{array}{l}\text { CEIVAP } \\
\left.\text { (US\$ year-1) }^{-1}\right)\end{array}$ & $\%$ & $\begin{array}{c}\text { PCJ } \\
\left(\text { US\$ year-1) }^{-1}\right)\end{array}$ & $\%$ & $\begin{array}{c}\text { CBHSF } \\
\left(\text { US\$ year }^{-1}\right)\end{array}$ & $\%$ & $\begin{array}{l}\text { CBH-DOCE } \\
\text { (US\$ year-1) }^{-1}\end{array}$ & $\%$ \\
\hline Irrigation & $761,589.77$ & 82.7 & $1,027,842.12$ & 85.5 & $145,563.79$ & 48.9 & $177,911.30$ & 41.7 \\
\hline $\begin{array}{l}\text { Animal } \\
\text { watering }\end{array}$ & $1,526.88$ & 0.2 & $2,060.36$ & 0.2 & 452.34 & 0.2 & 481.53 & 0.1 \\
\hline $\begin{array}{l}\text { Human } \\
\text { supply }\end{array}$ & $19,539.19$ & 2.1 & $21,092.77$ & 1.8 & $18,523.40$ & 6.2 & $19,718.45$ & 4.6 \\
\hline Sanitation & $80,382.32$ & 8.7 & $89,064.07$ & 7.4 & $78,594.43$ & 26.4 & $169,876.90$ & 39.9 \\
\hline $\begin{array}{l}\text { Industrial } \\
\text { supply }\end{array}$ & $57,145.68$ & 6.2 & 61,689.37 & 5.1 & $54,174.81$ & 18.2 & $57,669.95$ & 13.5 \\
\hline $\begin{array}{l}\text { Sand } \\
\text { mining }\end{array}$ & 212.23 & 0.02 & 606.46 & 0.05 & 532.59 & 0.2 & 567.89 & 0.1 \\
\hline Total & 920,396.08 & 100 & $1,202,355.16$ & 100 & $297,841.36$ & 100 & $426,226.03$ & 100 \\
\hline
\end{tabular}

The grants for electricity production (Table 1) were not subject to the charging simulation due to the fact that it is regarded as a small hydroelectric plant (SHP) and, therefore, charging for water use is not allowed, as per Law No. 7,990/1989, along with Law No. 9,427/1996. As a result, according to ANA (2016), small hydropower plants (SHP) and hydroelectric generating stations (HGS) are not subject to paying for water use from the grants. In addition, the charges from SHP and HGS depend on regulation by competent federal authority (CEMIG, 2016; IGAM, 2011).

Thus, considering the estimated values for the simulations shown in Table 2, charges in the Grande River Basin, based on different charging methods, could allow investments of US\$1,202,355.16 (PCJ), US\$920,396.08 (CEIVAP), US\$426,226.03 (CBH-DOCE) or US\$297,841.36 (CBHSF) in this basin.

\subsection{Analysis of the relative cost of charges on production cost of water users}

For irrigated agriculture, the lowest relative cost on annual production costs was $0.19 \%$, simulated by the CBHSF's method; PCJ's method would cause a greater impact $(1.31 \%)$. The simulation using CEIVAP's method would provide a relative cost of $0.97 \%$, taking the 
progressivity of the farming method into account, as shown in Table 3.

The percentages ranged from $0.002 \%$ (CBHSF) to $0.011 \%$ (PCJ) for animal watering. CEIVAP's method led to an impact of $0.008 \%$, considering the progressivity, and $0.010 \%$, taking the entirety of the collection into account. The results showed that, for this user segment, the methods would cause a small increase in production costs when charging began to be enforced.

Charging methods caused a similar impact on water use for human supply. The percentages ranged from $0.26 \%$ (CBHSF) to $0.30 \%$ (PCJ), proving the adoption of any of the charging methods studied to be similar for this segment.

Table 3. Relative cost (RC) of charging for water use in the Grande River Basin considering different methods.

\begin{tabular}{lccccc}
\hline & $\begin{array}{c}\text { CEIVAP } \\
\mathbf{( \% )}\end{array}$ & $\begin{array}{c}\text { PCJ } \\
\mathbf{( \% )}\end{array}$ & $\begin{array}{c}\text { CBHSF } \\
\mathbf{( \% )}\end{array}$ & $\begin{array}{c}\text { CBH-DOCE } \\
\mathbf{( \% )}\end{array}$ & $\begin{array}{c}\text { Production cost } \\
\text { (US\$ year }^{-1} \text { ) }\end{array}$ \\
\hline RC Irrigation & 0.97 & 1.31 & 0.19 & 0.23 & $78,307,499.12$ \\
RC Animal watering & 0.008 & 0.011 & 0.002 & 0.003 & $18,240,605.20$ \\
RC Human supply & 0.28 & 0.30 & 0.26 & 0.28 & $7,098,642.96$ \\
RC Sanitation & 0.18 & 0.20 & 0.18 & 0.29 & $57,608,270.24$ \\
RC Industrial supply & 0.08 & 0.08 & 0.07 & 0.08 & $73,563,327.54$ \\
RC Sand mining & 0.23 & 0.66 & 0.58 & 0.62 & $92,058.62$ \\
\hline
\end{tabular}

The relative cost for sanitation ranged from 0.18\% (CEIVAP/CBHSF) to $0.29 \%$ (CBHDOCE). The highest percentage for the CBH-DOCE was caused by the public unitary prices for catchment and effluent release, which are higher than the other methods. Even so, the impact generated by the CBH-DOCE is insignificant, so it does not substantially affect the user segment.

For industrial supply, regardless of the charging method adopted, the impact generated would be basically the same, around $0.08 \%$. The variation is minimal, fluctuating from $0.07 \%$ to $0.08 \%$, resulting in a difference of $0.01 \%$ percentage point. For this segment, the choice of any method would maintain similar levels of collection.

The simulation for the riverbed sand mining sector demonstrated a similar impact in the different methods that were studied. Only the result of CEIVAP's method is different from the others, due to the fact that it carries a different equation to calculate charging for this segment. In addition, the impact generated by the CEIVAP does not exceed the $0.5 \%$ of production costs limit set by the method.

According to DAE (São Paulo, 2004), it can be asserted that international experiences have shown that the objective of obtaining financial resources prevails over environmental objectives, except in the Netherlands ${ }^{1}$, where the charging instrument has been effective both in revenue generation and pollution control, due to the high cost for the final user.

${ }^{1}$ The Basic Unit Price (PUB) varies from US\$ 30.00 to US\$ 60.00, depending on the region. 
The relative cost of charging for water use on users' production costs, considering the different charging methods, is low for most users and, consequently, ends up not fulfilling one of its purposes - which is to stimulate efficient water use (ANA, 2011). In order to set a maximum limit for charges in the Grande River Basin, which is under the responsibility of the River Basin Committee, the socioeconomic and environmental characteristics of the Western region of Bahia must be taken into account.

The Basin Committee must promote discussion of the issues of the impact of charging, minor uses, priorities for implementing charges and other issues related to water resources, considering the situation of the basin. These discussions will serve as a basis to set and approve the plan of the basin's water resources, which is of the utmost importance in implementing the charging and promotion of investments, geared towards improving the quality of the water and general environmental conditions of the hydrographic basin.

In the Grande River Basin, agriculture is highly technological and business-oriented, and is considered the largest consumer of water resources from the basin. With a maximum impact of $0.5 \%$ in production costs, as simulated by the CEIVAP, few users will be concerned about water use efficiency just because they are being charged. The farmer might be concerned because of the unavailability of water, i.e., when the grant is not sufficient to irrigate the entire area of interest, but not necessarily due to charging, since water charges would mean an average cost of 9.70 US\$ per ha ${ }^{-1}$ per year ${ }^{-1}$, as shown in Table 4.

Table 4. Charging cost for water use for irrigation in the Grande River Basin.

\begin{tabular}{lc}
\hline Method & Charging value (US\$ ha $\mathbf{~}^{\mathbf{1}}$ year $^{-1}$ ) \\
\hline CEIVAP & 13.98 \\
PCJ & 18.87 \\
CBHSF & 2.67 \\
CBH-DOCE & 3.27 \\
\hline Average & $\mathbf{9 . 7 0}$ \\
\hline
\end{tabular}

Using CEIVAP's method as an example, and considering the reduction of the relative cost of $0.97 \%$ presented in Table 3 for $0.5 \%$, the charging cost would fall from 13.98 US\$ per ha ${ }^{-1}$ per year ${ }^{-1}$, as in Table 4, to 7.18 US\$ per ha-1 per year ${ }^{-1}$. Thus, it can be verified that the setting of a low impact limit for agriculture will not stimulate more rational use, nor will it meet the objectives of charging for water use.

In Israel, for example, farmers are charged according to their water use, and prices range from 0.18 US\$ per $\mathrm{m}^{-3}$ to 0.29 US\$ per $\mathrm{m}^{-3}$, despite strong agricultural pressure for price increases. Charging is still not used as a primary source in Israel to induce the rational use of water (Cornish et al., 2004). The Brazilian levels are far below that, but to evaluate whether charging encourages conscious consumption at current values, the analysis should consider marginal costs and benefits provided by the charging, which is not the purpose of this study.

All existing charging methods in Brazil opt to charge considering the volume of water that was collected and/or the volume of released effluent, i.e., through volumetric methods. The same is true in relation to the granting of the right to water resources by the various regulatory agencies. In Bahia, for example, the ordinances of authorization or concession for water catchment are published with the flow granted in $\mathrm{m}^{3}$ per day ${ }^{-1}$, including the purpose of use and location of the land.

Cornish et al. (2004) state that the volumetric methods may not be of interest for developing countries due to the difficulty in installing measurement devices for users on a large scale, along with the costs therein. The authors also highlight the fragility of the devices when 
it comes to fraud or accidental damage.

Despite this, Foster and Hope (2017) demonstrated in their studies in rural communities in Kenya that volumetric basis charging provides a higher volume of revenue than charging flat fees.

Considering the statement by Cornish et al. (2004), measuring the water catchment will be the main problem in the Grande River Basin, as in order to estimate consumption recognized coefficients in the literature may be adopted for various segments, notably irrigated agriculture.

CEIVAP's and PCJ's methods are similar and generate intermediate impact in comparison with other methods, mainly for agriculture. These methods generate relative costs of charging of less than $1 \%$ on the production costs of user activities, except for irrigation (but this may be adjusted), and provide a higher collection than CBHSF and CBH-DOCE, which may allow larger investments for the improvement of the basin.

Because of the significant differences in the circumstances found between the Grande River and the PBS Basins, mainly in regard to irrigated agriculture, one of the possible adjustments to CEIVAP's method could involve not setting a limit for the impact on the agricultural sector. If this limit is set, it must not be insignificant; otherwise, it will not encourage rational water use.

In the Grande River Basin, pressures on water resources arising from the intensive use of water for irrigation and hydroelectric development projects for small hydroelectric plants (SHP) generate conflicts over water use. In a study performed by Almeida et al. (2014), they could identify segments of the Branco and Fêmeas Rivers, tributaries of the Grande River, with flows granted above legal limits established in the State of Bahia.

This context of dispute and water scarcity, at some points in the basin, is an incentive for instituting a water usage charge. With the implementation of this instrument by NWRP, in addition to encouraging rational use, charging would provide the acceptance of water as an economic good that is limited, encouraging users of water resources to request volumes closer to their real needs. Indeed, for Letsoalo et al. (2007), charging reduces the use of water, directly affecting the quantity of water consumed.

In this sense, Almeida and Curi (2016) propose a charging model with specific equations to discourage both granting requests above the users' needs and the use of water resources in a volume higher than that granted.

It is important to emphasize that the actions aimed to prevent water use conflicts must be carried out based on studies on the vulnerability of water resources (Almeida et al. 2014). These studies will support the process of granting and, consequently, the establishment of charging, the application of which must be consolidated through legal instruments.

Thus, considering the aspects discussed in this section, the CEIVAP or PCJ methods would be the most suitable ones in the context of the Grande River Basin, since the methods' parameters are in line with existing activities in the basin. Furthermore, these methods are closest to supplying economic and environmental prospects for charging, although adjustments are suggested.

However, it is important to emphasize that the introduction of charges for water use must be approved and established by the Grande River Basin Committee, which should institute the method and values to be charged.

\section{CONCLUSIONS}

Based on the analysis of the results, we can conclude that:

- Irrigation represents the usage with the largest number of grants and flow of water collected from the Grande River Basin.

\section{IPABH}

Rev. Ambient. Água vol. 13 n. 5, e2238 - Taubaté 2018 
- The simulations undertaken have confirmed the resources that could be raised and applied in the interventions for the water resources plan of the basin, providing a basis for discussions on the establishment of this instrument of water-resource management in the Grande River Basin.

- There is a possibility of implementing charges for water use in the Grande River Basin, with either the CEIVAP or PCJ method appearing to be the most suitable, given that the parameters of these mechanisms are in line with existing activities in the basin.

- Due to the significant differences between the Grande River- and PBS Basins, mainly with regard to irrigated agriculture, one of the possible adjustments to CEIVAP's method would involve not setting a limit for the economic impact on the agricultural sector. If this limit is set, it must not be insignificant; otherwise, it will not encourage rational water use.

\section{REFERENCES}

AGÊNCIA NACIONAL DE ÁGUAS - ANA (Brasil). Cobrança pelo uso de recursos hídricos. Brasília, 2016.

AGÊNCIA NACIONAL DE ÁGUAS - ANA (Brasil). Conjuntura dos recursos hídricos no Brasil. Brasília, 2013.

AGÊNCIA NACIONAL DE ÁGUAS - ANA (Brasil). Nota Informativa no. 03/2011/SAG. Brasília, 2011.

AGÊNCIA NACIONAL DE ÁGUAS - ANA (Brasil) et al. Plano decenal de recursos hídricos da bacia hidrográfica do rio São Francisco - PBHSF (2004-2013) - Resumo Executivo. Brasília, 2004.

ALMEIDA, M. A. de; CURI, W. F. Gestão do uso de água na bacia do Rio Paraíba, PB, Brasil com base em modelos de outorga e cobrança. Revista Ambiente \& Água, v. 11, n. 4, p. 989-1005, 2016. http://dx.doi.org/10.4136/ambi-agua.1820

ALMEIDA, W. A.; MOREIRA, M. C.; SILVA, D. D. Applying water vulnerability indexes for river segments. Water Resource Management, v. 28, p. 4289-4301, 2014. http://dx.doi.org/10.1007/s11269-014-0745-5

ARAÚJO, J. F.; DE CASTRO, A. P.; COSTA, M. M. C. et al. Microbial Ecology, v. 64, p. 760, 2012. https://doi.org/10.1007/s00248-012-0057-3

ASSOCIAÇÃO DE AGRICULTORES E IRRIGANTES DA BAHIA - AIBA. Anuário agropecuário do Oeste da Bahia: safra 2014/15. Barreiras: Ouza, 2015.

BRASIL. Departamento Nacional de Produção Mineral - DNPM. Sumário mineral 2014. Brasília, 2015.

BRASIL. Lei Federal n 9.433, de 8 de janeiro de 1997. Institui a Política Nacional de Recursos Hídricos, cria o Sistema Nacional de Gerenciamento de Recursos Hídricos, regulamenta o inciso XIX do art. 21 da Constituição Federal, e altera o art. $1^{\circ}$ da Lei $\mathrm{n}^{\circ}$ 8.001, de 13 de março de 1990, que modificou a Lei $n^{\circ}$ 7.990, de 28 de dezembro de 1989. Diário Oficial [da] União, 9 jan. 1997.

BRASIL. Ministério do Meio Ambiente. Desenvolvimento de matrizes de coeficientes técnicos para recursos hídricos no Brasil. Brasília-DF, 2011.

BUNGE. Relatório de sustentabilidade. São Paulo, 2012. 
CARVALHO, F. M. V.; MARCO JÚNIOR, P.; FERREIRA, L. G. The Cerrado into pieces: habitat fragmentation as a function of landscape use in the savannas of central Brazil. $\begin{array}{llllll}\text { Biological Conservation, } & \text { v. 142, po9. }\end{array}$ http://dx.doi.org/10.1016/j.biocon.2009.01.031

CENTRO DE ESTUDOS AVANÇADOS EM ECONOMIA APLICADA - CEPEA. Custos de produção da pecuária de corte. 2016. Available: http://cepea.esalq.usp.br/boi/?page=372. Access: 23 fev. 2016.

COMITÊ DA BACIA HIDROGRÁFICA DO RIO DOCE - CBH-DOCE. Deliberação CBHDOCE No. 26 de 31 de março de 2011. Governador Valadares, 2011.

COMITÊ DA BACIA HIDROGRÁFICA DO RIO SÃO FRANCISCO - CBHSF. Deliberação CBHSF no. 56/2010. Belo Horizonte, 2010.

COMITÊ DA BACIA HIDROGRÁFICA DO RIO SÃO FRANCISCO - CBHSF. Deliberação CBHSF No. 40/2008. Belo Horizonte, 2008.

COMITÊ DAS BACIAS HIDROGRÁFICAS DOS RIOS PIRACICABA, CAPIVARI E JUNDIAÍ - PCJ. Deliberação dos Comitês PCJ no. 160/2012. Piracicaba, 2012.

COMITÊ DAS BACIAS HIDROGRÁFICAS DOS RIOS PIRACICABA, CAPIVARI E JUNDIAÍ - PCJ. Deliberação Conjunta dos Comitês PCJ no. 78/2007. Piracicaba, 2007.

COMITÊ DE INTEGRAÇÃO DA BACIA HIDROGRÁFICA DO RIO PARAÍBA DO SUL CEIVAP. Deliberação CEIVAP no. 218/2014. Resende, 2014.

COMPANHIA NACIONAL DE ABASTECIMENTO - CONAB (Brasil). Custos de produção culturas de verão - Safra 2014-2015. Available: http://www.conab.gov.br/conteudos.php?a=1554\&t=2. Access: 2 Apr. 2015.

COMPANHIA DE ELETRICIDADE DO ESTADO DE MINAS GERAIS - CEMIG. Cobrança pelo uso da água. 2016. Available: https://goo.gl/jQVnS8. Access: 3 June 2016.

CONFEDERAÇÃO NACIONAL DA INDÚSTRIA - CNI. Uso da água no setor industrial Brasileiro: matriz de coeficientes técnicos. Brasília, 2013.

CONSELHO NACIONAL DO MEIO AMBIENTE - CONAMA (Brasil). Resolução n. 357. Diário Oficial [da] União, 18 mar. 2005.

CORNISH, G. et al. Water charging in irrigated agriculture: an analysis of international experience. Roma: FAO, 2004.

FEITOSA, G. D. S.; SANTOS, G. B. Identification of depositional landforms in environment of confluence of the Branco and Grande rivers, west region of Bahia State (Brazil): by trend surface. International Journal of river Basin Management, v. 14, n. 4, p. 407412, 2016. http://dx.doi.org/10.1080/15715124.2016.121532410.1080/15715124.2016.1215324

FOSTER, T.; HOPE, R. Evaluating waterpoint sustainability and access implications of revenue collection approaches in rural Kenya. Water Resources Research, v. 53, p. 1473-1490, 2017. http://dx.doi.org/10.1002/2016WR019634 
GARCÍA-VALIÑAS, M. A.; GONZÁLEZ-GÓMEZ, F.; PICAZO-TADEO, A. J. Is the price of water for residential use related to provider ownership? Empirical evidence from Spain. Utilities Policy, v. 24, p. 59-69, 2013. https://doi.org/10.1016/j.jup.2012.07.009

INSTITUTO DO MEIO AMBIENTE E RECURSOS HÍDRICOS - INEMA. CBH Grande: caracterização da bacia. 2014. Available: http://www.inema.ba.gov.br/gestao-2/comitesde-bacias/comites/cbh-grande. Access: 10 nov. 2014.

INSTITUTO MINEIRO DE GESTÃO DAS ÁGUAS - IGAM. Proposição de metodologia para implantação da cobrança pelo uso de recursos hídricos na bacia hidrográfica do rio Santo Antônio. Belo Horizonte, 2011.

JOHNSON, N.; WHITE, A.; PERROT-MAÎTRE, D. Developing markets for water services from forests: issues and lessons for innovators. Washington: Forest Trends; World Res. Institute; The Katoomba Group, 2002.

LETSOALO, A.; BLIGNAUT, J.; WET, T.; WIT, M.; HESS, S.; TOL, R. S. J. Triple dividends of water consumption charges in South Africa. Water Resources Research, v. 43, 2007. http://dx.doi.org/10.1029/2005WR004076

KLINK, C. A.; MACHADO, R. B. Conservation of the Brazilian Cerrado. Conservation Biology, v. 19, p. 707-713, 2005. http://dx.doi.org/10.1111/j.1523-1739.2005.00702.x

MOREIRA, M. C.; SILVA, D. D. Atlas hidrológico da bacia hidrográfica do Rio Grande. Barreiras: Gazeta Santa Cruz, 2010.

NAZER, D. W.; SIEBEL, M. A.; VAN DER ZAAG, P.; MIMI, Z.; GIJZEN, H. J. A financial, environmental and social evaluation of domestic water management options in the west bank, Palestine. Water Resource Management, v. 24, p. 4445-4467, 2010. http://dx.doi.org/10.1007/s11269-010-9667-z10.1007/s11269-010-9667-z

PASSO, D. P. et al. Caracterização geomorfológica do município de São Desidério, BA. Planaltina, DF: Embrapa Cerrados, 2010. Escala 1:50.000.

PEREIRA, S. B.; PRUSKI, F. F.; SILVA, D. D.; RAMOS, M. M. Estudo do comportamento hidrológico do rio São Francisco e seus principais afluentes. Revista Brasileira de Engenharia Agrícola e Ambiental, v. 11, n. 6, p. 615-622, 2007.

PLOEG, C. G. V.; SOMMERFELD, L. Charging for water use in Canada: a workbook of the central principles, key questions, and initial steps. Calgary: Canada West Foundation, 2011.

SANTA CATARINA. Diário Oficial [de] Santa Catarina, n. 19.336, de 21 de maio de 2012.

SÃO PAULO (Estado). Departamento de Águas e Energia Elétrica - DAE. Impacto da cobrança pelo uso da água por tipo de usuário, SRH. São Paulo, 2004.

SANTOS, G. B.; CASTRO, P. T. A. Sedimentological characteristics and geochemistry of lake waters of the Grande river basin, west of Bahia State (Brazil). International Journal of river Basin Management, v. 14, n. 4, p. 431-440, 2016. http://dx.doi.org/10.1080/15715124.2016.12153234:410.1080/15715124.2016.1215323 $4: 4$ 
SOUZA, R. C.; MENDES, I. C.; REIS-JUNIOR, F. B. et al. Shifts in taxonomic and functional microbial diversity with agriculture: How fragile is the Brazilian Cerrado? BMC Microbiology, v. 16, p. 42, 2016. http://dx.doi.org/10.1186/s12866-016-0657-z

VEIGA, L. B. E.; MAGRINI, A. The Brazilian Water Resources Management Policy: Fifteen Years of Success and Challenges. Fifteen Years of Success and Challenges. Water Resource Management, v. 27, p. 2287-2302, 2013. http://dx.doi.org/10.1007/s11269013-0288-110.1007/s11269-013-0288-1

WOLF, A. T.; KRAMER, A.; CARIUS, A.; DABELKO, G. Managing water conflict and cooperation. In: ASSADOURIAN, E. et al. State of the World: redefining global security, 2005. Washington: The WorldWatch Institute, 2005. 